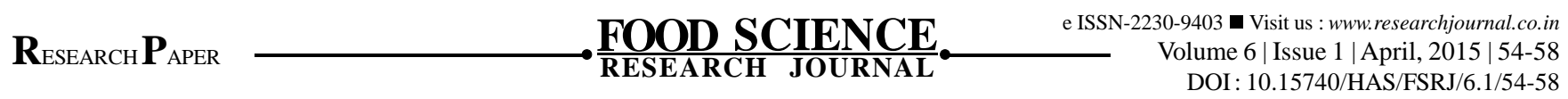

\title{
Studies on standardization of herbal aonla spread by using licorice and ginger extract
}

\author{
G.J. Bhavsar, P.N. Satwadhar, R.R. Andhale, H.M. Syed and I.H. Syed
}

\begin{abstract}
The present investigation was carried out to standardize the procedure for development of herbal aonla spread. The effect of addition of various concentrations of licorice (viz., 3\%, 5\% and 7\%) in aonla spread and prepared samples were organoleptically evaluated by trained panelist and it was found that sample with 5 per cent licorice extract got the highest score in terms of overall acceptability and this sample was used for further investigation. Moreover, effect of various concentration of ginger extact such as 8 per cent, 10 per cent and 12 per cent in aonla spread with 5 per cent licorice is studied and sample with 10 per cent ginger extract was found superior as compared to all other samples in terms of colour, taste, texture and overall acceptability. It is concluded that good quality of herbal aonla spread can be prepared by using the 5 per cent licorice and 10 per cent ginger extract.
\end{abstract}

Key Words : Aonla spread, Licorice extract, Ginger extract, Herbal spread

How to cite this article : Bhavsar, G.J., Satwadhar, P.N., Andhale, R.R., Syed, H.M. and Syed, I.H. (2015). Studies on standardization of herbal aonla spread by using licorice and ginger extract. Food Sci. Res. J., 6(1): 54-58.

Email: ganeshb.foodtech@gmail.com

Associate Authors' :

P.N. SATWADHAR, R.R. ANDHALE, H.M. SYED AND I.H. SYED, Department

of Food Chemistry and Nutrition, College of Food Technology, Vasantrao Naik Marathwada Krishi Vidyapeeth, PARBHANI (M.S.) INDIA 